Kabán Annamária és férje 2018-ban egy nagyszabású tanulmánykötetben összegezte Dsida Jenővel foglalkozó addigi kutatásait (Tárt kapukhoz fényösvény viszen. Dsida Jenő költészete és müfordításai). Ez a roppant gazdag tartalmú és elméletileg is igényes tanulmánygyüjtemény egy rövidesen tető alá hozható Dsida-monográfia ígéretét hordozta magában. De a sors úgy akarta, hogy ez legyen kutatásaik záróköve, egyben újabb tudósnemzedékek ösztönzője és segítője.

A múlt év novemberében együtt búcsúztattak el minket, nyugdíjba vonulókat, a Miskolci Egyetemen: őt hatvanöt évesen, látszólag makkegészségesen, vidáman, további alkotásokra készülve, engem a hetvenediket is betöltve, a sokévi munkába egy kissé belefáradva. S most mégis nekem kellett nekrológot írnom őróla, nem pedig neki énrólam. 2019. július 5-én volt a búcsúztatása Miskolcon. Az ott felolvasott méltatások, emlékezések külön kis füzetben is megjelentek: A szív elárul, mert világít. Kabán Annamária búcsúztatása címmel. Ezzel a kiadvánnyal egy napon azonban még egy könyvet hozott a posta, a szerző utolsó, immár posztumusz kötetét, amely Égten élek címmel hat esszét tartalmaz az erdélyi magyar költészetről: egyet a szabadvers-építő Bartalis Jánosról, kettőt Reményik Sándorról és hármat Kovács András Ferenc Babits- és József Attila-imitációiról meg Mozart Rekviemjére reflektáló, K. 626 címü verséről. Ez utóbbi verselemzés volt Kabán Annamária utolsó munkája, amelyet a megbetegedése, rosszulléte előtti estén fejezett be. Jelképes és egyben hátborzongató, hogy amiképpen Mozart a Rekviemmel a saját halotti miséjét írta, az erről szóló vers elemzése lett Kabán Annamária búcsúüzenete. Igazi filológushoz illően a tanulmány (és egyben az életmü) nem saját mondattal, hanem idézettel zárul: „,...] İ́gy juthatsz / Földi örömhöz, szentült, / Több szeretethez.”

Legyen tehát ez, a „szeretet” Kabán Annamária búcsúszava valamennyiünkhöz. Kedves Anikó, Isten veled, nyugodj békében!

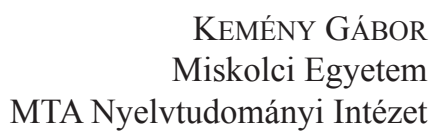

\title{
Andor József 70 éves*
}

A sokat szidott vagy éppen felmagasztalt Facebooknak van egy, az udvarias társas viszonyokat elősegítő, a leechi együttérzés maximáját teljesítő, kitünő szolgáltatása: emlékezteti a használóit arra, hogy ismerőseik közül az adott napon vagy a közelmúltban kinek van/volt születésnapja. De nemcsak emlékeztet, hanem rögtön fel is ajánlja a köszöntés lehetöségét: Írj születésnapi köszöntöt az idővonalára...

A Magyar Nyelvtudományi Társaság a Facebookot évtizedekkel megelőzve vezette be azt a szokást, hogy nyomon követi, közössége tagjai közül ki az, aki az adott évben tölti be 70., 80., 90., illetve 100. életévét és felkéri a születésnapost jól ismerő tagtársak valamelyikét, hogy köszöntse a kerek évfordulóst. Andor József 2019. március 14-én lett 70 éves. A születésnap előtt a Magyar Nyelvtudományi Társaság felajánlotta nekem: Mondj és írj születésnapi köszöntőt... Megörültem a lehetőségnek, megtiszteltetés számomra, hogy az ünnepeltet köszönthetem a Társaság nevében (is).

* Elhangzott 2019. április 17-én a Magyar Nyelvtudományi Társaság felolvasó ülésén.

DOI: 10.18349/MagyarNyelv.2019.3.371 
Andor József 1949. március 14-én született Pécsett. Egyetemi tanulmányait Debrecenben, a Kossuth Lajos Tudományegyetem angol-orosz szakán végezte, 1973-ban diplomázott. Debreceni diákévei alatt 1968-tól 1973-ig Korponay Béla, Papp Ferenc és Dezső László voltak az érdeklődését meghatározó tanárai, olyan kutatók, akikkel később baráti kapcsolatba is került. Évfolyamtársa és jó barátja volt és jelenleg is az Kecskés István, akivel számos témában, de különösen a pragmatika területén azonos módon gondolkodik.

Andor József 2012 végéig, nyugdíjba vonulásáig a felsőoktatásban dolgozott, hallgatók ezreit oktatta, egyaránt részt vett a graduális és posztgraduális képzésben. A Pécsi Tudományegyetem Angol Nyelvészeti Tanszékéről ment nyugdíjba címzetes egyetemi tanárként. A doktori képzésben azonban azóta is részt vesz, a Pécsi Tudományegyetem és a Debreceni Tudományegyetem Nyelvtudományi Doktori Iskoláiban oktató, illetve témavezető. Témavezetésével öten szereztek doktori fokozatot. A többi magyarországi nyelvtudományi doktori iskola doktori cselekményeinek is aktív részese, opponál, vizsgáztat, bizottsági tagságot vállal.

Andor József kutatási tevékenysége rendkívül szerteágazó, ugyanakkor az általa követett szemléletmód és alkalmazott módszertan révén egymással összefüggésbe hozható területekre terjed ki. Fő kutatási témakörei a következők: a) az angol és a magyar nyelv leírása, a fonetika/fonológia kivételével valamennyi nyelvi reprezentációs szinten, b) általános nyelvészet, c) kognitív nyelvészet (föként keret-szemantika), d) empirikus alapú nyelvészeti kutatások, e) korpusznyelvészet, f) szövegtan, különös tekintettel a szövegkoherencia vizsgálatára, főként médiaszövegekben, szépirodalmi szövegekben, a viccekben (részben különböző kultúrákban megjelenő állatviccekben) és g) lexikális szemantika, lexikális pragmatika.

Publikációs tevékenysége imponáló, az MTMT tanúsága szerint 141 közleménye jelent meg, amelyekre 392 hivatkozást kapott. Mindemellett mintegy 130 hazai és nemzetközi konferencián adott elö. Kiterjedt nemzetközi kapcsolatokkal rendelkezik, a külföldi nyelvészkollégák közül különösen nagy hatással volt rá Charles J. Fillmore (UC Berkeley), John M. Anderson (University of Edinburgh), Stanley Starosta (University of Hawaii at Manoa) és Yoshihiko Ikegami (University of Tokyo), akikkel szoros személyes barátságot is kötött.

Andor József új müfajt vezetett be a tudományos nyelvészeti publikációk világába. Szakmai interjúkat készített a nyelvtudomány, a filozófia, a kognitív pszichológia nemzetközi és hazai „óriásaival”. Ezek az interjúk jelentős hazai és nemzetközi szakfolyóiratokban, szakkönyvekben jelentek/jelennek meg. A hazai nyelvészek közül Kiefer Ferenccel, Petőfi Sándor Jánossal (magyarul és angolul), Szépe Györggyel (kétszer), Tolcsvai Nagy Gáborral, Korponay Bélával készített interjúja jelent meg, idén pedig a Magyar Nyelvőrben publikálja legújabb interjúját É. Kiss Katalinnal, akit nemsokára köszöntünk 70. születésnapja alkalmából a Magyar Nyelvtudományi Társaságban. A külföldi nyelvészek közül Noam Chomskyval (kétszer - jelenleg dolgoznak a harmadik interjún, amelynek a központi témája az ún. belső beszéd lesz), John R. Searle-lel, George Lakoff-fal, Charles J. Fillmore-ral, Teun van Dijkkal, Ronald Langackerrel, Ray Jackendoff-fal, Douglas Biberrel, Anna Wierzbickával, James Pustejovskyval, Herbert H. Clarkkal és John M. Andersonnal készített és jelentetett meg rendkívül izgalmas, érdekfeszítő interjút. Egy-egy ilyen interjúra Andor József hosszú hónapokig készül, áttanulmányozza az interjúalany munkásságát, az adott szakterület kérdésfeltevéseit, problematikáját és az interjút szakavatott beszélgetőtársként készíti.

Andor József publikációs tevékenysége mellett folyóiratok, könyvsorozatok szerkesztőjeként, szerkesztőbizottsági tagjaként is szolgálja a hazai és a nemzetközi nyelvészkö- 
zösséget. A HUMOR: International Journal of Humor Research (Berlin and New York: Mouton de Gruyter) címü folyóiratnál és a The Behavioral and Brain Sciences (Cambridge: Cambridge University Press) című folyóiratnál szerkesztőbizottsági tanácsadó, a debreceni Studies in Linguistics, a pécsi Studies in Linguistics, valamint a Jelentés és Nyelvhasználat címü folyóiratok szerkesztőbizottsági tagja, az Equinox Kiadó (Sheffield) Pragmatic Interfaces címü könyvsorozatának szerkesztőbizottsági tagja, a PTE által megjelentetett Határtalanul címü könyvsorozatnak pedig szerkesztőbizottsági tanácsadója.

Andor József szakmai társaságoknak is tagja, most csak a számára oly kedves Magyar Nyelvtudományi Társaság Pécsi Csoportját emelem ki, amelynek titkára volt Temesi Mihály elnöksége idején az 1980-as években, majd „Miska Bácsi” halála után az elnöke 1988 és 2005 között.

Andor József szakmai tevékenységét a hazai és a nemzetközi nyelvészközösség ismeri és elismeri. Bizonyítja ezt az, hogy a hazai és nemzetközi nyelvészeti kutatások kiemelkedő egyéniségei örömmel vállalkoznak arra, hogy velük interjút készítsen. Az angol nyelvészet terén végzett kiemelkedő munkásságáért a Magyar Anglisztikai Társaság 2019ben az Országh László-díjat neki ítélte oda. Hazai és külföldi munkatársai, pályatársai az Argumentum címü folyóirat (http://argumentum.unideb.hu) születésnapi különszámával köszöntötték Andor Józsefet, jelezve ezzel megbecsülésüket, tiszteletüket, szeretetüket.

Andor József nyugdíjba vonulása után tovább folytatja aktív kutatómunkáját, tele van ötletekkel, tervekkel. Személyes beszélgetéseink során lelkesen osztja meg ezeket, amelyek közül néhányat most kiemelek. Az általa készített interjúkat magyar és angol nyelvü kötetben szeretné megjelentetni, ki kívánja adni egybegyüjtve azokat a tanulmányait, amelyekben szépirodalmi müveket elemez nyelvészeti (szövegtani) eszközökkel, Brassai Sámuel mondattani munkásságát angol nyelvre szeretné fordítani és megjelentetni Amsterdamban, a John Benjamins Kiadó nyelvtudomány-történeti könyvsorozatában, angol és magyar grammatikai jelenségeket szeretne vizsgálni különféle müfajú szövegekben.

Amikor nem dolgozik és nem a családjával foglalatoskodik, akkor Andor József zongorázik. Kisgyermekkorában kiderült, hogy abszolút hallása van és kitűnő zenei érzéke. Egy időben zongoramüvésznek készült, de aztán pályája más irányban alakult. A zongorajáték azonban megmaradt, könnyüzenét és jazzt játszott/játszik, ha kellett, bárzongoristaként is fellépett kongresszusokon. Nem meglepő ez, a legkiválóbb nyelvészeknek mindig közük volt a zenéhez és/vagy a matematikához. A zene mellett Andor Józsefet a többi müvészet, főként a festészet és a szobrászat mütárgyainak esztétikai vonatkozású ismerete, tárgyalása érdekli. Szenvedélyes könyvgyüjtő, szakmai könyvtára mintegy 8000 kötetet számlál. Gasztronómiai ismeretei is lenyügözőek, kedvencei a különböző teatípusok, teafajták, ezeknek szakavatott ismerője és „müélvező” fogyasztója.

Végül hadd szóljak pár szót az ünnepelthez füződő személyes élményeimről. 1983ban másodéves magyar-orosz-általános nyelvészet szakos egyetemi hallgatóként hallottam először Andor Józsefröl Károly Sándortól, az akkori József Attila Tudományegyetem Általános Nyelvészeti Tanszékének vezetőjétől. Mikor elmondtam, hogy a nyelvhasználat, a szöveg, illetve a diskurzusok világa érdekelne, Károly Sándor azt javasolta, hogy Andor József munkáit olvassam. Szót fogadtam és rögtön elolvastam Andor József A nyelvleírás szövegtanának egyik lehetséges megközelítése című tanulmányát (In: SZATHMÁRI ISTVÁN VÁRKONYI, IMRE szerk., A szövegtan a kutatásban és az oktatásban. Magyar Nyelvtudományi Társaság, Budapest, 1979: 33-45). Az azóta eltelt időben Andor József sok más 
munkája is inspirálóan hatott rám. Sokáig csak az írásos publikációiból ismertem Andor Józsefet, mígnem 2000 januárjában Erdőtarcsán, az IPrA budapesti konferenciájának nemzetközi szervező- és absztraktbíráló bizottsága tagjaiként személyesen megismerkedtünk egymással, és az absztraktok értékelésével eltöltött három nap alatt barátságot kötöttünk. Mivel én akkortájt fiatal anyuka voltam egy négy és egy nyolc éves kislánnyal, Erdőtarcsára a férjem és a gyerekeim is elkísértek. A közös étkezések és séták hatására a kislányaim megjegyezték maguknak Andor Józsefet mint a kedves, szakállas pécsi bácsit. Ha később Jóska olyankor keresett telefonon otthon, amikor én nem voltam elérhető, a kislányaim mindig úgy adták át az üzenetet, hogy „Anya, keresett a kedves, szakállas pécsi bácsi”, amely leírás néhány évvel később kiegészült az ősz hajú jelzővel, miután 2010-ben Madridban, az Intercultural Pragmatics Konferencián ismét találkoztak vele. A madridi konferencia a tudományos súlya mellett azért is emlékezetes maradt a számomra, mert Madridban hallottam elöször Jóskát a fözésről beszélni: megtudtuk tőle, hogyan készül az igazi paella és milyen az eredeti valenciai paella serpenyő. Személyes találkozásaink mellett Jóskával rendszeresen beszélünk telefonon szakmai dolgokról és családi történésekről egyaránt. Nagyon megtisztelő számomra, hogy nyomon követi a pályámat, támogat, bátorít. Külön élmény számomra hallani, ahogy megszólít: Eni, Encsi, Enci. Kollégáim közül Jóska és Maleczki Márta az, aki becézve fordul hozzám, barátságuk mellett talán ezzel is kifejezve azt, hogy van egy közös dunántúli identitásunk, „fődik vagyunk”. Jóska másik nyelvhasználati szokása, amelyre felfigyeltem, a helyeslö jajaja. Nálunk otthon, Celldömölkön, az igenlő ja forma legfeljebb egyszer ismétlödik, azaz jaja. A pécsiek, így Jóska nyelvhasználatában viszont minimum kétszeri ismétlődés fordul elő, azazjajaja. Ez a nyelvhasználatbeli eltérés azonban semmilyen megértési problémát nem okoz a társalgásainkban.

Kedves Jóska! 70. születésnapod alkalmából szeretettel köszöntelek a Magyar Nyelvtudományi Társaság, a magyar nyelvészközösség, a magam és a családom nevében. Kívánom, hogy a terveid mind megvalósuljanak, majd aztán újabb terveid szülessenek. Nem sürgetve az időt, én türelmesen várni fogom, hogy az eredetileg titkos, de engedelmeddel most nyilvánosságra hozott, megállapodásunknak megfelelően Te köszönts engem a Magyar Nyelvtudományi Társaság ünnepi ülésén a 90. születésnapomon. Isten éltessen eröben, egészségben, jókedvben!

NÉMETH T. ENIKÖ

Szegedi Tudományegyetem

\section{É. Kiss Katalin 70 éves*}

Nem könnyü feladat olyasvalakinek az eddigi szakmai életútját röviden méltatni, aki a nyelvtudományban olyan széles körben ismert és elismert, mint ünnepeltünk, É. Kiss Katalin. Tetézi a kihívást, hogy a bemutatandó életmú maga nem egyszerủen tiszteletet parancsolóan kiterjedt, hanem mind a mai napig ugyanolyan iramban bővül és gazdagodik, mint korábban bármikor. Mégis örömmel vállaltam el a megtisztelő feladatot, hogy erre

\footnotetext{
* Elhangzott a Nyelvtudományi Társaság 2019. június 4-i felolvasó ülésén.
} 